\title{
A STATE OF THE NATION ADDRESS - EDUCATION FOR DEVELOPMENT
}

\author{
Nnamdi O. Madichie \\ Nnamdi Azikiwe University, Awka
}

$\boldsymbol{\&}$

\author{
Nkemdili Au. Nnonyelu \\ Nnamdi Azikiwe University, Awka
}

The featured papers in this issue cover parts of Nigeria from Oyo in the Southwest to Kaduna and Edo States in the North and Midwest, respectively. The topics range from the need for technical and vocational education, through the that of a sound national policy, to social responsibility matters championed by higher education for the betterment of society and economic development.

In the first paper, Onyebuchi \& Wogor, posit that "Schools in Africa have not given much attention to technical education." This is rather problematic considering that, and according to the authors, "technical education is the kind of training that concerns a particular aspect of science, occupation or profession which has both theoretical and practical instructions that are given to those who are going to be employed in commerce and industry using tools and machinery for the operation, production, preservation and distribution of goods and services." The authors go on to decry this lack of attention as a recipe for the backwardness and unpreparedness of African graduates. According to them, the neglect could "be the main reason Africa is still backward technologically." The authors examined the concept of "technical education as a key to industrialization in Africa," and sought to highlight the importance and role of technical education in African industrial advancement, and the challenges facing technical education in Africa. In concluding, the authors opined that "technical education takes the lead for industrialization in Africa because through it, youths and adults will be equipped with the requisite skills and knowledge needed for economic growth and development."

Adeleye in the second paper explores the case of Oyo State in the Southwest of Nigeria. He argues that "Business Education and entrepreneurship are regarded as two of the most important driving forces of welfare development in our nation. In the National Policy on Education in Nigeria, government to a great extent see Business Education and entrepreneurship as a crucial vehicle that drive the nation towards future economic growth." A key factor for future innovativeness and growth in society is the supply of competent individuals that are motivated, especially among Business Education students to become entrepreneurs inside and outside of established organizations. Drawing from a sample of 350 student population of 791 across three Colleges of Education in the State (i.e., Emmanuel Alayande College of Education, Federal College (Special) Oyo, and The College of Education, Lanlate), the author finds that "Business Education mentoring was rated 'well taught' while entrepreneurship education was rated Poorly taught." It was concluded that Business Education students rate relevant mentoring and entrepreneurship skills poorly in comparison to what is in the curriculum.

In the third paper, Onugu, Usman \& Moore, take the conversation to Northern Nigeria by interrogating how tertiary education institutions in Kaduna State were being socially responsible. In a nutshell these authors, sought to assess "the social responsibility of cooperative organizations resident in tertiary institutions in Kaduna State, Nigeria." The study was based on a sample size of 312 from a population of 1,412 registered members of cooperative organizations resident in tertiary institutions in the State. The judgmental sample consisted of six cooperative organizations that were selected one from each of the six tertiary institutions (The selected tertiary institutions were Nuhu Barnalli Polytechnic, Zaria; School of Nursing-Makarfi; Federal Polytechnic, Kaduna; Kaduna State University, Kaduna; College of Education Gidan Waya and School of Midwifery, Kafanchan) - selected two from each senatorial zone in the State. The data seemed to suggest that cooperative organizations had not met their social responsibilities to their host communities. While noting the numerous challenges faced by the 
investigated organisations, there seemed to be some positive - albeit tentative, gains. The major challenges include lack of fund, poor relationship with host communities, and hostile attitude of the host communities. The study therefore recommended that cooperative organizations in tertiary institutions in Kaduna State should strive to imbibe the culture of concern for host community as a cardinal cooperative principle. To realize this, they should intensify drive for membership as a means of increasing their funding capacity and also seek beneficial partnerships with local and international donor agencies to enhance their capacity to deliver on social responsibility.

Onyeizugbe, Musah \& Obuebite in the fourth, and final paper interrogated how workplace conflict and organisational politics impacts upon tertiary education in the Midwestern State of Edo. According to them, "the increasing rate of organisational politics and workplace conflict has been a great challenge to tertiary institutions in Edo State. This study examined how organisational politics affects workplace conflict among tertiary institutions in Edo State. The objective of this study is to examine the relationship that exists between self-interest and communication breakdown drawing insights from six higher education institutions in Edo State (notably, University of Benin, Benin city; Institute of Technology and Management, Usen; Ambrose Alli University, Ekpoma; College of Education, Igueben; Auchi Polytechnic, Auchi; Institute of Physical and Health Education, Afuze). The findings revealed a significant positive relationship between self-interest and communication breakdown among the selected tertiary institutions in Edo State and that organisational politics will definitely lead to workplace conflict if not properly managed.

Overall, the papers in this issue have touched upon a range of complexities in education from the Southwest of the country to the North highlighting the role of, especially business education, to the socioeconomic development of Nigeria in particular, and African in more general terms. 